\title{
Fenomena Catcalling sebagai Bentuk Pelecehan Seksual secara Verbal terhadap Perempuan di Jakarta
}

\author{
Angeline Hidayat, Yugih Setyanto \\ angelinehidayat6@gmail.com,yugihs@fikom.untar.ac.id
}

Fakultas Ilmu Komunikasi Universitas Tarumanagara, Jakarta

\begin{abstract}
Catcalling, a familiar term that is often heard especially in big cities like Jakarta. In catcalling, there is a form of communication in which the offender gives verbal expression to the victim through whistling and also comments about body shape by attacking the sexual attributes of the victim. However, this is a problem because there is an ambiguity in the meaning of the community about catcalling as a joke or sexual harassment, especially against women. The purpose of this research is to know about the phenomena and forms of communication from catcalling. This research is qualitative research using phenomenology method. Theories used in this research are verbal communication theory, patriarchal culture, feminism, stereotypes and gender, and catcalling. This study uses interviews with key informants and informants, participant observation, literature study, and documentation to collect data. The result of this research is that catcalling is a verbal sexual harassment and is part of the rape culture.
\end{abstract}

Keywords: catcalling, gender, human behavior, patriarchy, verbal communication

\begin{abstract}
Abstrak
Catcalling, sebuah istilah yang tidak asing untuk didengar terutama di daerah perkotaan besar seperti di Jakarta. Dalam catcalling, terdapat bentuk komunikasi di mana pelaku memberikan ekspresi verbal terhadap korbannya misalnya melalui siulan dan juga komentar-komentar tentang bentuk tubuh mereka dengan menyerang atribut seksual korban. Namun, hal ini menjadi sebuah permasalahan karena terdapat ambiguitas makna yang terdapat di masyarakat tentang catcalling sebagai candaan atau pelecehan seksual terutama terhadap perempuan. Adapun maksud dari penelitian ini adalah untuk mengetahui tentang fenomena dan juga bentuk komunikasi dari catcalling tersebut. Penelitian ini merupakan sebuah penelitian kualitatif yang menggunakan metode fenomenologi. Teori yang digunakan dalam penelitian ini adalah teori komunikasi verbal, budaya patriarki, feminisme, stereotip dan gender, dan catcalling. Penelitian ini menggunakan beberapa metode yaitu wawancara dengan informan kunci dan informan, observasi partisipan, studi pustaka, dan dokumentasi untuk mengumpulkan data. Hasil dari penelitian ini adalah catcalling merupakan pelecehan seksual secara verbal dan merupakan bagian dari rape culture.
\end{abstract}

Kata Kunci: catcalling, gender, komunikasi verbal, patriarki, perilaku manusia

\section{Pendahuluan.}

Berbagai kriminalitas terjadi setiap harinya di jalanan. Salah satunya merupakan pelecehan seksual yang biasanya sering didapatkan terjadi di jalan raya. Biasanya terjadi secara verbal atau yang sering disebut dengan istilah catcalling. Pada masa ini, perilaku itu telah berkembang dan menjadi sebuah fenomena di masyarakat. Mengapa hal ini dapat disebut sebagai sebuah fenomena? Karena kejadian tersebut merupakan hal-hal yang nyata dan dapat disaksikan menggunakan pancaindra. 
Menurut hasil Survei Pelecehan Seksual di Ruang Publik dengan persentase sebanyak 64 persen dari 38.766 perempuan, 11 persen dari 23.403 laki-laki, dan 69 persen dari 45 gender lainnya pernah mengalami pelecehan di ruang publik. Kebanyakan dari korban mengaku bahwa mereka pernah mengalami pelecehan yang diterima secara verbal, yaitu komentar atas tubuh sebanyak 60 persen, fisik seperti disentuh sebanyak 24 persen dan visual seperti main mata sebanyak 15 persen. (Sumber: Survei Pelecehan Seksual di Ruang Publik). Walaupun hasil survei tersebut sudah terbit, namun masih banyak masyarakat yang belum aware mengenai isu ini. Hal ini dikarenakan adanya stereotip gender yang dibentuk oleh patriarki sehingga menimbulkan makna ganda yaitu catcalling sebagai candaan dan catcalling sebagai pelecehan seksual.

Oleh karena itu, berdasarkan latar belakang di atas, maka dalam penelitian ini peneliti mengambil judul "Fenomena Catcalling sebagai Bentuk Pelecehan Seksual secara Verbal terhadap Perempuan di Jakarta".

\section{Landasan Teori}

Menurut Effendy, dalam Ilmu Komunikasi, Teori \& Praktik Komunikasi, komunikasi adalah proses yang dilakukan individu untuk menyampaikan pesan terhadap individu lainnya. Hal ini dilakukan karena individu tersebut memiliki tujuan untuk memberikan informasi, mengubah sikap, pendapat atau perilaku dari individu tersebut. Adapun penyampaian pesan tersebut dapat dilakukan secara lisan (secara langsung) maupun melalui media (secara tidak langsung) (Effendy, 2017).

Dalam Liliweri, Makna Budaya dalam Komunikasi Antar Budaya, ada tiga jenis pesan verbal yaitu: verbal vokal, verbal visual, verbal vocal-visual. Pada vokal adalah ketika pesan verbal disampaikan menggunakan suara (secara vokal). Pada visual adalah ketika mengucapkan serangkaian pesan verbal tidak hanya menggunakan sebatas ucapan tetapi juga menggunakan visualisasi agar visual tersebut juga dapat dilihat atau bahkan didengar menggunakan telinga oleh penerimanya. Pada vokalvisual adalah pengucapan kata-kata atau rangkaiannya menggunakan vokal dan dibantu lagi dengan adanya visualisasi (Liliweri, 2009).

Dalam Komunikasi Manusia: Teori dan Praktek dalam Penyampaian Gagasan oleh Dr. Eko Harry Susanto, terdapat beberapa aksioma komunikasi yang berkembang dalam penelitian salah satunya adalah komunikasi adalah perilaku individu. Dalam aksioma komunikasi tersebut, komunikasi merupakan rangkaian dorongan verbal maupun non-verbal, yang menghasilkan tanggapan secara paralel. Komunikasi mencerminkan tingkah laku individu yang didorong oleh rangsangan-rangsangan yang dapat menimbulkan hubungan perilaku reaktif berdasarkan karakter mekanistis. Tanggapan terhadap rangsangan, diperkuat dengan feedback yang positif maupun negatif terhadap perilaku kondisi yang sesungguhnya diharapkan (Susanto, 2018).

Menurut Harold Lasswell (1948) dalam buku Suciati Teori Komunikasi dalam Multi Perspektif, mengusulkan model komunikasi yang terdiri dari lima unsur. Unsurunsur tersebut adalah: Who (sumber : siapa), Says what (pesan : mengatakan apa), In which channel (saluran komunikasi : pada saluran yang mana, To whom (penerima : kepada siapa), With what effect (pengaruh : dengan dampak apa). Kelima unsur tersebut berperan dalam menciptakan sebuah bentuk komunikasi (Suciati, 2017).

Kaum feminis radikal memiliki sebuah kecurigaan bahwa karena pemisahan ranah publik dan juga ranah privat ini menyebabkan adanya ketertindasan terhadap perempuan. Pada pemisahan ini terdapat pengertian bahwa ranah privat berada pada tingkatan yang lebih rendah di bawah ranah publik. Oleh karena itu, tumbuhlah sistem 
yaitu sistem patriarki. Kalangan feminis radikal meyakini ada penyebab dasar dari ketertindasan perempuan yaitu seksualitas dan sistem gender (Arivia, 2018).

Menurut Bhasin (2000) dalam bukunya Memahami Gender, relasi gender menjadi tidak seimbang dikarenakan patriarki. Secara umum, patriarki diartikan dominasi yang dilakukan oleh laki-laki; kata "patriarki" didefinisikan sebagai kuasa yang dimiliki oleh ayah atau "patriarch" (kepala keluarga), dan sejak awal mula telah digunakan untuk mendeskripsikan secara spesifik sebagai "keluarga yang didominasi oleh laki-laki -- keluarga tersebut, yang beranggotakan perempuan, laki-laki yang berusia lebih muda, anak-anak, budak dan pembantu rumah tangga, berada dalam kuasa yang dimiliki oleh laki-laki pemimpin keluarga ini. Saat ini, istilah itu digunakan untuk merujuk kepada kekuasaan laki-laki, kepada relasi kuasa, dalam keadaan lakilaki berada di tingkatan yang lebih tinggi dari perempuan, dan menjadi ciri dari sistem di mana perempuan terus direndahkan menggunakan banyak cara (Bhasin, 2003).

Adapun dirangkum oleh Taylor dan Moghaddam (1994), berdasarkan penelitian yang dilakukan oleh sejumlah pakar, bahwa stereotip itu merupakan kesan bersifat kaku yang tidak sesuai dengan kenyataan, keyakinan berlebihan yang sebenarnya tidak akurat dan bersifat rasional. Kemudian adanya sifat penting yang lainnya menurut Hogg dan Abraham (1988) bahwa stereotip merupakan keyakinan yang dimiliki bersama, artinya bagian terbesar dari masyarakat akan setuju dengan isi stereotip kelompok tertentu. Sebagai contoh, di kalangan masyarakat barat ada konsensus yang diterima secara meluas bahwa orang Irlandia itu bodoh, orang kulit hitam tidak bertanggung-jawab, wanita adalah makhluk emosional, dan lain sebagainya. Keyakinan itu diterima dengan mengabaikan sejumlah pengecualian, misalnya bahwa ada wanita yang tidak emosional (Susetyo, 2010).

Secara umum, Taylor dan Porter (1994) mengategorikan stereotip tersebut terhadap dalam beberapa jenis. Jenis-jenis tersebut adalah stereotip rasial-etnis, stereotip kultural, dan stereotip gender. Menurut Fakih (1996), stereotip gender merupakan pemberian label terhadap jenis kelamin tertentu. Dalam hal ini, lebih banyak menyasar terhadap perempuan, contohnya adalah stereotip tentang perempuan berdandan dengan tujuan untuk membuat lawan jenisnya yaitu laki-laki merasa tertarik terhadapnya. Oleh karena itu, pada kasus kekerasan dan pelecehan seksual sering disangkutpautkan dengan stereotip ini. Tidak jarang, perempuan objek kekerasan dan pelecehan seksual tersebut seringkali menjadi pihak yang justru disalahkan (Susetyo, 2010).

Chhun (2011) mengidentifikasikan catcalling sebagai: penggunaan kata-kata yang tidak senonoh, ekspresi secara verbal dan juga ekspresi non-verbal yang kejadiannya terjadi di tempat publik, contohnya: di jalan raya, di trotoar, dan perhentian bus. Secara verbal, catcalling biasanya dilakukan melalui siulan atau komentar mengenai penampilan dari seorang wanita. Ekspresi nonverbal juga termasuk lirikan atau gestur fisik yang bertindak untuk memberikan penilaian terhadap penampilan seorang wanita (Chhun, 2011).

Macmillan et al (2000) memberikan argumen bahwa salah satu dari efek yang terjadi akibat catcalling termasuk dengan membatasi kebebasan seseorang untuk bergerak. Catcalling menimbulkan rasa takut pada para korban dan membuat mereka merasa bahwa mereka harus waspada ketika mereka sedang berada di luar dan sekitarnya. Melsen (2004) mengatakan bahwa catcalling dilakukan untuk menyebabkan rasa takut dan mendominasi korbannya (Ellaine, 2018). 
MacMillan et al. (2000) membuktikan bahwa tempat-tempat umum merupakan tempat dimana pelecehan oleh orang asing sering terjadi. Karena pelecehan yang dilakukan oleh orang asing, tempat-tempat seperti taman dan angkutan umum dirasakan kurang aman bagi wanita yang sering mengalami catcalls (Eastwood, 2015).

\section{Metode Penelitian}

Dalam penelitian ini disusun dengan menggunakan pendekatan kualitatif. Penelitian kualitatif yang dimaksud adalah penelitian yang bertujuan untuk memahami fenomena yang dialami oleh subjek penelitian. Peneliti berusaha memahami tentang perilaku, persepsi, motivasi, tindakan, dan lain-lain milik informan secara holistik, dan mendeskripsikannya ke dalam bentuk kata-kata serta bahasa, dengan konteks yang khusus yang alamiah sehingga memanfaatkan berbagai metode alamiah. (Moleong, 2017:6). Penelitian ini bersifat deskriptif yaitu dalam penelitian ini berusaha untuk menuturkan yang menjadi rumusan dari masalah berdasarkan data-data. Data-data yang dikumpulkan adalah data yang berupa kata-kata dan gambar. Data yang didapat bukanlah angka-angka (Moleong. 2017).

Penelitian ini menggunakan metode fenomenologi. Menurut Orleans dalam Kuswarno, Metodologi Penelitian Komunikasi Fenomenologi Konsepsi, Pedoman, dan Contoh Penelitiannya, mengatakan bahwa penelitian menggunakan metode fenomenologi tidaklah sama dengan ilmu pengetahuan sosial konvensional lain. Penelitian ini biasanya dilakukan pada tingkatan metasosiologis, yaitu penelitian dengan menunjukkan premis-premis melalui analisis deskriptif yang didapatkan dari prosedur situasional serta bangunan sosialnya. Pada fenomenologi, peneliti berusaha untuk mengetahui pemahaman yang dimiliki informan terhadap fenomena yang muncul dalam kesadarannya. Fenomena yang dialami oleh informan adalah entitas dari sesuatu yang benar-benar ada dalam dunia (Kuswarno, 2009).

Peneliti menggunakan beberapa metode mengumpulkan data di antaranya adalah: wawancara, observasi partisipan, studi kepustakaan, dan juga dokumentasi. Narasumber yang diwawancarai yaitu Budi Wahyuni Wakil Ketua Komnas Perempuan 2015-2019.

Menurut Bogdan dan Biklen, dalam Moleong, Metode Penelitian Kualitatif. Analisis data kualitatif adalah usaha untuk bekerja dengan menggunakan data-data, mengorganisasikannya, setelah itu memilah data tersebut dan menjadikannya sebagai satuan yang kemudian dapat dikelola oleh peneliti, mensintesiskannya, lalu mencari agar dapat menemukan pola, menemukan hal-hal penting serta hal yang dipelajari setelah itu memutuskan hal yang mana saja yang dapat diceritakan lagi pada orang lain (Moleong, 2017).

Agar keabsahan data tersebut bisa diterapkan, maka diperlukan teknik untuk memeriksaan data yang dilakukan menggunakan kriteria tertentu. Menurut Moleong, dalam Ruslan, Metode Penelitian: Public Relations dan Komunikasi, ada empat kriteria yang digunakan untuk memeriksa keabsahan data, yaitu derajat kepercayaan (credibility), keteralihan (transferability), kebergantungan (dependability), dan kepastian (confirmability) (Ruslan, 2017).

Peneliti hanya menggunakan tiga dari empat kriteria yang ada yaitu credibility, dependability, dan confirmability karena ketiga kriteria itu sudah bisa menjamin keabsahan data yang diperoleh oleh peneliti dalam penelitian ini. 
Angeline Hidayat, Yugih Setyanto: Fenomena Catcalling sebagai Bentuk Pelecehan Seksual secara Verbal terhadap Perempuan di Jakarta

\section{Hasil Temuan dan Diskusi}

Hasil penelitian yang ditemukan oleh peneliti adalah sebagai berikut: catcalling adalah sebuah istilah yang merujuk pada suatu bentuk verbal yaitu siulan atau komentar yang bertujuan untuk mencari perhatian namun dengan memberikan perhatian kepada atribut-atribut seksual tertentu sehingga perbuatan ini termasuk dalam kategori pelecehan seksual. Catcalling biasanya terjadi di tempat umum dan dilakukan oleh orang asing yang tidak saling kenal.

Chhun (2011) mengidentifikasikan catcalling sebagai: penggunaan kata-kata yang tidak senonoh, ekspresi secara verbal dan juga ekspresi non-verbal yang kejadiannya terjadi di tempat publik, contohnya: di jalan raya, di trotoar, dan perhentian bus. Secara verbal, catcalling biasanya dilakukan melalui siulan atau komentar mengenai penampilan dari seorang wanita. Ekspresi nonverbal juga termasuk lirikan atau gestur fisik yang bertindak untuk memberikan penilaian terhadap penampilan seorang wanita (Chhun, 2011).

Dalam Liliweri, Makna Budaya dalam Komunikasi Antar Budaya, ada tiga jenis pesan verbal yaitu: verbal vokal, verbal visual, verbal vokal-visual. Pada vokal adalah ketika pesan verbal disampaikan menggunakan suara (secara vokal). Pada visual adalah ketika mengucapkan serangkaian pesan verbal tidak hanya menggunakan sebatas ucapan tetapi juga menggunakan visualisasi agar visual tersebut juga dapat dilihat atau bahkan didengar menggunakan telinga oleh penerimanya. Pada vokalvisual adalah pengucapan kata-kata atau rangkaiannya menggunakan vokal dan dibantu lagi dengan adanya visualisasi (Liliweri, 2009).

Jenis-jenis pesan verbal yang disampaikan oleh pelaku catcalling kepada korbannya ada beberapa macam diantaranya; dalam bentuk nada misalkan suara kecupan, suara ciuman dari jauh, atau siulan, Yang kedua, komentar, biasanya mengomentari bentuk tubuh, atau secara kalimat tidak melecehkan tetapi dikatakan dengan tujuannya melecehkan, misalnya salam. Ada juga yang terang-terangan mengatakan hal yang vulgar mengenai korban. Selain itu, pandangan mata yang berlebihan juga termasuk pelecehan karena membuat yang dipandang merasa tidak nyaman. Misalnya, seseorang yang memandangi orang lain dari ujung kaki hingga ujung kepala.

Pemahaman mengenai catcalling di masyarakat masih sangat rendah karena adanya pewajaran. Masih adanya anggapan bahwa catcalling adalah hal yang biasa atau merupakan bentuk dari candaan dan pujian menyebabkan hal ini terus terjadi berulang-ulang. Menurut Budi Wahyuni perilaku ini bisa menjadi langgeng dan terus menerus terjadi juga dikarenakan oleh adanya peran budaya patriarki. Beliau memberikan pendapatnya mengenai hal ini dalam wawancara dengan mengatakan:

"Iya. Pewajaran dan pelanggengan budaya patriarki tadi. Budaya patriarki itu kan ingin memposisikan laki-laki lebih tinggi dari perempuan. Ini kan sudah menciptakan relasi kuasa yang satu tinggi, yang satu rendah. Nah, salah satu akar dari kekerasan termasuk kekerasan seksual. Pelecehan seksual bagian dari kekerasan seksual adalah relasi kuasa yang timpang. Jadi, relasi kuasa yang timpang akan melahirkan itu, melecehkan, merendahkan, menyerang atribut seksual tertentu, menyerang harkat martabat perempuan gitu loh."

Menurut Bhasin (2000) dalam bukunya Memahami Gender, relasi gender menjadi tidak seimbang dikarenakan oleh patriarki. Secara umum, patriarki memiliki pengertian sebagai dominasi yang dilakukan oleh laki-laki; kata "patriarki" didefinisikan sebagai kuasa yang dimiliki oleh ayah atau "patriarch" (kepala 
keluarga), dan sejak awal mula telah digunakan untuk mendeskripsikan secara spesifik sebagai "keluarga yang didominasi oleh laki-laki"-keluarga tersebut, yang beranggotakan perempuan, laki-laki yang berusia lebih muda, anak-anak, budak dan pembantu rumah tangga, berada dalam kuasa yang dimiliki oleh laki-laki pemimpin keluarga ini. Saat ini, istilah itu digunakan untuk merujuk kepada kekuasaan laki-laki, kepada relasi kuasa, dalam keadaan laki-laki berada di tingkatan yang lebih tinggi dari perempuan, dan menjadi ciri dari sistem di mana perempuan terus direndahkan menggunakan banyak cara (Bhasin, 2003).

Catcalling merupakan salah satu produk dari budaya patriarki. Penempatan laki-laki di atas perempuan menyebabkan terjadinya relasi kuasa sehingga tidak tercapai kesetaraan gender. Budaya patriarki ini bukan hanya dilanggengkan oleh lakilaki namun juga ada peran perempuan yang turut serta di dalamnya. Perempuan dalam budaya patriarki sudah terbiasa didominasi oleh laki-laki. Karena perbedaan kedudukan itu, perempuan dianggap sebagai objek.

Menurut Fakih (1996), stereotip gender merupakan pemberian label terhadap jenis kelamin tertentu. Dalam hal ini, lebih banyak menyasar terhadap perempuan, contohnya adalah stereotip tentang perempuan berdandan dengan tujuan untuk membuat lawan jenisnya yaitu laki-laki merasa tertarik terhadapnya. Oleh karena itu, pada kasus kekerasan dan pelecehan seksual sering disangkutpautkan dengan stereotip ini. Tidak jarang, perempuan objek kekerasan dan pelecehan seksual tersebut seringkali menjadi pihak yang justru disalahkan (Susetyo, 2010:26).

Selain itu, budaya patriarki juga memberikan tekanan pada laki-laki. Budaya ini menciptakan keadaan di mana laki-laki dianggap jantan apabila sudah melakukan catcalling. Tekanan tersebut yang menyebabkan laki-laki akhirnya melakukan hal itu karena adanya paksaan dari luar. Kedua hal ini dalam patriarki menyebabkan perilaku ini terus menerus terjadi dan belum bisa diakhiri.

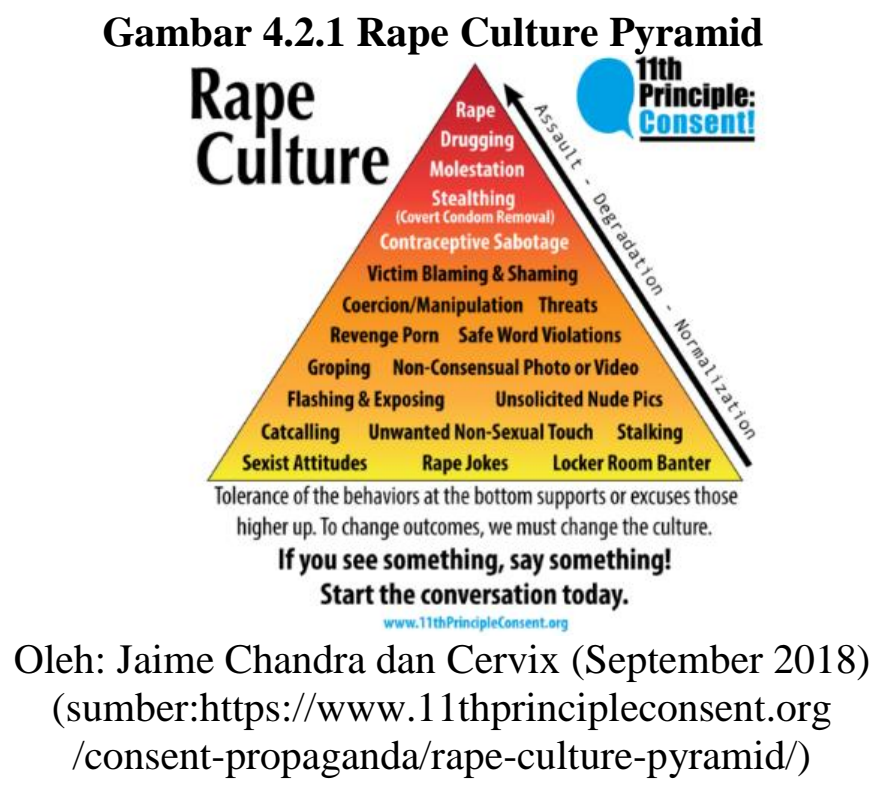

Catcalling merupakan sebuah bentuk dari pelecehan yang ringan dan terdapat dalam layer kedua piramida rape culture. Pada layer pertama terdapat perilaku seksis dan rape jokes yang terjadi akibat adanya mindset. Catcalling berada pada layer kedua yaitu pelaku sudah melakukan aksi. Perilaku ini tidak boleh diwajarkan dan dianggap normal. Apabila tidak ada batasan terhadap perilaku dan sanksi yang jelas, maka 
Angeline Hidayat, Yugih Setyanto: Fenomena Catcalling sebagai Bentuk Pelecehan Seksual secara Verbal terhadap Perempuan di Jakarta

kemungkinan besar pelaku akan berproses ke tingkat selanjutnya yaitu kekerasan yang lebih berbahaya.

\section{Simpulan}

Fenomena catcalling ini sebenarnya sudah terjadi sejak lama dan menjadi sebuah permasalahan yang ada di masyarakat terutama di perkotaan besar seperti Jakarta. Fenomena ini kurang mendapatkan perhatian karena minimnya edukasi yang menyebabkan ketidaktahuan mengenai pemahaman tentang catcalling. Masyarakat masih menganggap makna catcalling sebagai ambigu antara candaan atau pujian dan bentuk dari pelecehan seksual terutama terhadap perempuan.

Catcalling adalah pelecehan seksual. Pelaku melakukan catcalling kepada korban dengan menyerang atribut seksual yang dimilikinya. Penyerangan itu dilakukan melalui ekspresi verbal seperti siulan, suara kecupan, dan gestur main mata dengan tujuan untuk mendominasi dan membuat korban merasa tidak nyaman. Budaya patriarki menempatkan posisi laki-laki di atas perempuan yang menyebabkan ketimpangan di antara laki-laki dan lawan jenisnya yaitu perempuan. Adanya ketimpangan dalam relasi kuasa menyebabkan perempuan dianggap sebagai objek. Hal ini menyebabkan kerentanan terhadap perempuan sehingga perempuan menjadi korban dari kekerasan dan pelecehan seksual.

Namun, ternyata yang menjadi korban dalam praktik patriarki ini bukan hanya terjadi terhadap perempuan saja. Ada juga akibat yang bisa terjadi pada laki-laki karena adanya tekanan sosial terhadap laki-laki. Anggapan bahwa laki-laki baru bisa dianggap jantan apabila sudah melakukan catcalling membuat perilaku ini menjadi langgeng dan sulit dihentikan. Catcalling merupakan bagian dari rape culture. Perilaku ini berada di layer kedua dari piramida rape culture. Walaupun sebenarnya masih berada di tingkat pelecehan yang ringan namun perilaku ini tidak bisa dianggap wajar atau normal. Perilaku ini akan semakin sulit dihilangkan apabila masyarakat terbiasa untuk mewajarkan catcalling.

Oleh karena itu, edukasi mengenai pemahaman mengenai catcalling sebagai pelecehan seksual yang terjadi secara verbal terutama terhadap perempuan merupakan hal yang sangat penting. Target utamanya adalah kepada calon pelaku serta calon korban agar calon pelaku tidak melakukan catcalling dan calon korban bisa melapor apabila hal itu terjadi padanya.

\section{Ucapan Terima Kasih}

Penyusunan dari hasil penelitian yang dilakukan oleh peneliti ini dapat terlaksana karena adanya bantuan serta dukungan dari berbagai pihak. Peneliti ingin menyampaikan terima kasih kepada semua yang ikut terlibat dan telah membantu peneliti selama proses penelitian ini, yaitu:

1. Kepada Budi Wahyuni, Wakil Ketua Komnas Perempuan periode 2015-2019 dan Yani Oktaviana, dosen, rapper, dan aktivis perempuan sebagai informan kunci dalam penelitian ini. Kepada Anindya Restuviani, co-director Hollaback! Jakarta dan Monica Devina admin akun Instagram @Dearcatcallers.id sebagai informan dalam penelitian ini.

2. Keluarga serta teman-teman yang selalu mendukung dan memberikan semangat untuk menyelesaikan laporan penelitian skripsi ini. 


\section{Daftar Pustaka}

Arivia, Gadis. (2018). Filsafat Berperspektif Feminist, Edisi Kedua. Cetakan ke-1. 116-117. Jakarta: JYP Press..

Bhasin, Kamla. (2003). Memahami Gender, Cetakan ke-3. 2627. Jakarta: Teplok Press.

Chhun, B. (2011). Catcalls: Protected speech or fighting words. Thomas Jefferson Law Review. Agustus 21, 2019. Terarsip di: https://www.yumpu.com/en /document/read/4936037/catcalls-protected-speech-or-fighting-wordsthomas-jefferson-

Effendy, Onong Uchjana. (2017). Ilmu Komunikasi, Teori \& Praktik. Bandung: PT. Remaja Rosdakarya.

Eastwood, E. (2015) What, Can't You Take a Compliment? A Qualitative Study of Catcalling. Agustus 22, 2019. Terarsip di: http://www.divaportal.org/ smash/record.jsf?pid=diva2\%3A1023177\&dswid $=3587$

Ellaine, Anne. (2018). Catcalling. Agustus 22, 2019. Terarsip di: https://www.scribd.com/document/372292281/Catcalling

Kuswarno, Engkus. (2009). Metode Penelitian Komunikasi: Fenomenologi, Konsepsi, Pedoman dan Contoh Penelitiannya. Bandung: Widya Padjajaran.

Liliweri, Alo. (2009). Makna Budaya dalam Komunikasi Antarbudaya. Yogyakarta: LKiS Yogyakarta.

Moleong, Lexy J. (2017). Metodologi Penelitian Kualitatif, Edisi Revisi. Bandung: PT. Remaja Rosdakarya.

Rape Culture Pyramid. (2018, September). November 10, 2019. https://www.11thprincipleconsent.org/consent-propaganda/rape culturepyramid/

Ruslan, Rosady. (2017). Metode Penelitian Public Relations dan Komunikasi. Jakarta: PT Raja Grafindo Persada.

Suciati. (2017). Teori Komunikasi dalam Multi Perspektif. Yogyakarta: Buku Litera Yogyakarta.

Survei Pelecehan Seksual di Ruang Publik. (2019) Jakarta: Change.Org., Jakarta Feminist Discussion Group, Hollaback! Jakarta, Lentera Sintas Indonesia, perEMPUan.

Susanto, Eko Harry. (2018). Komunikasi Manusia: Teori dan Praktik dalam Penyampaian Gagasan. Jakarta: Mitra Wacana Media. Edisi Pertama.

Susetyo, Budi DP. (2010). Stereotip dan Relasi Antarkelompok. Yogyakarta: Graha Ilmu. Edisi Pertama.

Wahyuni, Budi. (2019, Oktober 26). Wawancara pribadi. 